\title{
Article \\ Effect of Semi-Solid Processing on the Microstructure and Mechanical Properties of Aluminum Alloy Chips with Eutectic $\mathrm{Mg}_{2} \mathrm{Si}$ Intermetallics
}

\author{
Yong Guk Son ${ }^{1,2}$, Sung Soo Jung ${ }^{1,2}$, Yong Ho Park ${ }^{2, *}$ and Young Cheol Lee ${ }^{1, *(\text { CD }}$ \\ 1 Korea Institute of Industrial Technology (KITECH), 42-7 Baegyang-daero 804 beon-gil, Busan 46938, Korea; \\ a489756@kitech.re.kr (Y.G.S.); jungss@kitech.re.kr (S.S.J.) \\ 2 Department of Materials Science and Engineering, Pusan National University, 2 Busandaehak-ro 63 beon-gil, \\ Busan 46241, Korea \\ * Correspondence: Yhpark@pusan.ac.kr (Y.H.P.); yclee87@kitech.re.kr (Y.C.L.); Tel.: +82-51-510-3967 (Y.H.P.); \\ +82-05-309-7410 (Y.C.L.); Fax: +82-51-514-4457 (Y.H.P.); +82-05-309-7422 (Y.C.L.)
}

Citation: Son, Y.G.; Jung, S.S.; Park, Y.H.; Lee, Y.C. Effect of Semi-Solid Processing on the Microstructure and Mechanical Properties of Aluminum Alloy Chips with Eutectic $\mathrm{Mg}_{2} \mathrm{Si}$ Intermetallics. Metals 2021, 11, 1414 https://doi.org/10.3390/ met11091414

Academic Editor: Hana Jirková

Received: 2 August 2021

Accepted: 6 September 2021

Published: 7 September 2021

Publisher's Note: MDPI stays neutral with regard to jurisdictional claims in published maps and institutional affiliations.

Copyright: (C) 2021 by the authors. Licensee MDPI, Basel, Switzerland. This article is an open access article distributed under the terms and conditions of the Creative Commons Attribution (CC BY) license (https:/ / creativecommons.org/licenses/by/ $4.0 /)$.

\begin{abstract}
This study reports the microstructural changes and mechanical properties of high-strength aluminum alloy chips prepared in the semi-solid state at different temperatures, pressures, and holding times. In semi-solid processes, these processing parameters must be optimized because they affect the microstructure and mechanical properties of the chips. In microstructural analysis, these parameters clearly influenced the spheroidization of the aluminum matrix. The aluminum matrix was uniformly spheroidized after semi-solid processing, and the densities of the final samples increased with the holding time. After $30 \mathrm{~min}$ holding time at a given temperature, the density approached the theoretical density, but the compressive strength of the samples seriously deteriorated. Meanwhile, fracture surface investigation revealed a deformed $\mathrm{Mg}_{2} \mathrm{Si}$ phase, which is formed through a eutectic reaction. The strength of this phase significantly decreased after increasing the holding time of the semi-solid processing from 10 to $30 \mathrm{~min}$. Therefore, deformation of the $\mathrm{Mg}_{2} \mathrm{Si}$ phase caused by diffusion of aluminum into this phase can be a key factor for the decrease in the mechanical properties of samples fabricated with 30 min holding time.
\end{abstract}

Keywords: high-strength aluminum alloy; semi-solid; microstructure; mechanical properties; fracture surface

\section{Introduction}

The semi-solid process (SSP) offers several advantages in industry: short solidification times, low shrinkage, low forming temperatures, and a simple production process $[1,2]$. Recently, the SSP has been widely researched and applied in lightweight industries and is especially effective for producing lightweight automotive parts with excellent mechanical properties [3].

The main requirement for semi-solid (SS) state formation of alloys is the elimination of the dendritic structure during the solidification process. When the connected grains of a dendritic structure are eliminated, a spheroidal or non-dendritic structure is formed. This process takes place at a temperature between the solidus and the liquids. The microstructure of the alloy must be controlled by considering each variable in the SSP because the time, pressure, and temperature of the SSP influence the spheroidization process (breakage of the dendritic arms to create the spheroidal structure).

SSP-formed alloys with a spheroidal microstructure can produce high-quality casting parts with superior mechanical properties, lower segregation, and fewer other casting defects than in conventional casting [4,5]. In addition, it is known that alloys with a spheroidal microstructure can be easily fabricated by a technology involving thixo forming, rheo forming, and spray forming. Salleh et al. reported that alloys fabricated by thixo forming can reduce macro-segregation, porosity, and forming forces in the shaping process 
and can produce a variety of products, especially for the automotive industry [3]. Ivanchev et al. reported that rheo-forming technology is being developed as the demand for quality improvement and weight reduction of parts in the manufacturing industry is increasing, and this technology can minimize casting defects and increase elongation [6]. Malekan et al. found lower segregation and solidification shrinkage in the fine spheroidal structure obtained by the SSP than by conventional casting and solid-forming methods [7]. Judging from these results, parts manufactured by the SSP should possess higher mechanical properties than those manufactured by conventional casting. In fact, many studies have reported the high mechanical properties of products manufactured by the SSP [8-10]. In addition, research on improving the mechanical properties of aluminum (Al) alloys through the SSP is also proceeding steadily, and the mechanical properties of $\mathrm{Al}$ alloys have been improved mainly through the Al-Si [11-13], Al-Zn [14,15], and Al-Cu [16,17] alloy series. Unlike conventional SSP studies in which liquid or bulk-type materials are mainly used, $\mathrm{Al}$ chips are used in this study in order to investigate the effect of pressure and temperature on SSP structures, and there are few reports on the formation of semi-solid slurries using $\mathrm{Al}$ chips [18]. The present study aims to manufacture a high-strength aluminum alloy with improved mechanical properties through the SSP. The Al chips used in this study are made from the $\mathrm{Al}$ alloy developed by Kim et al. $[19,20]$. The alloy contains eutectic $\mathrm{Mg}_{2} \mathrm{Si}$ particles, which are considered to be the main reinforcement phase to increase mechanical properties. The SSP was run at different pressures, holding times, and temperatures, and the microstructure and mechanical properties of the resulting alloy were characterized. The compressive strengths, fracture behaviors, and Vickers hardness of the samples fabricated at different holding times were obtained and discussed, along with their microstructures. During the SSP, the eutectic $\mathrm{Mg}_{2} \mathrm{Si}$ particles showed deformation and fracture behavior with prolonged holding, and it was confirmed that the behavior of eutectic $\mathrm{Mg}_{2} \mathrm{Si}$ particles has a significant effect on the mechanical properties.

\section{Materials and Methods}

The raw matrix material was $\mathrm{Al}-8 \mathrm{Zn}-6 \mathrm{Si}-4 \mathrm{Mg}-2 \mathrm{Cu}$ wt $\%$ alloy with the following composition: commercial-purity Al (99.99\%; Nantong Tade Electronic Materials Technical Co., Ltd., Nantong, Jiangsu, China), pure Cu (99.997\%; RND Korea Co., Gwangmyeong, Korea), pure Zn (99.99\%; Sichuan Lande Industry Company Ltd., Chengdu, China), pure Mg (99.9\%; Luoyang Hualing Magnesium Co., Ltd., Luoyang, Henan, China), and commercial crystalline Si (99.9\%; Hoshine Silicon Co., Ltd., Pinghu, China). The alloy was processed into chips of length $3 \mathrm{~mm}$ and width $1 \mathrm{~mm}$ in a crushing apparatus. The chips $(8 \mathrm{mg})$ were placed into a graphite mold to form the alloy. A hot press furnace (HPF; Jungmin Industrial Co. Ltd., Vacuum Hot Press, Bucheon, Korea) capable of uniaxial pressuring was used as the furnace for manufacturing the samples. The K-type thermocouple was used to measure the temperature inside the furnace. The behaviors of the matrix manufactured at various pressures, temperatures, and holding times are described below and summarized in Table 1.

Group A: To optimize the SSP, the holding time and pressure were fixed at $30 \mathrm{~min}$ and $80 \mathrm{MPa}$, respectively, and the final processing temperature was varied as 550, 560, 570 , and $580^{\circ} \mathrm{C}$. The best process temperature for the SSP was $570{ }^{\circ} \mathrm{C}$. When the process temperature was reduced to 550 and $560{ }^{\circ} \mathrm{C}$, the $\mathrm{Al}$ matrix retained its dendritic structure, whereas the higher temperature $\left(580^{\circ} \mathrm{C}\right)$ exceeded the SS temperature, so the $\mathrm{Al}$ matrix was not spheroidized.

Group B: Process temperatures were set at 550,560 and $570{ }^{\circ} \mathrm{C}$ based on the optimum SSP. The process of group B increased the temperature to $450{ }^{\circ} \mathrm{C}$ and holding for $10 \mathrm{~min}$. After $10 \mathrm{~min}$ holding, the pressure was reduced from $80 \mathrm{MPa}$ to $0 \mathrm{MPa}$ ( $\mathrm{Pl}$ process). The temperature was then increased to the 3 different temperatures, 550,560 and $570{ }^{\circ} \mathrm{C}$. The $\mathrm{Al}$ matrix was spheroidized at all process temperatures, but owing to the low holding time, the samples were porous and their relative densities were below the theoretical density. 
Group C: To improve the relative densities of the group B samples, the holding time was increased from 10 to 30 min under the same temperature and pressure conditions. The relative densities were similar to the theoretical density, and the Al matrix was spheroidized at all temperatures.

Table 1. Spheroidization behaviors of the matrix formed at different process temperatures, pressures, and holding times.

\begin{tabular}{|c|c|c|c|c|}
\hline Sample Group & Process Temperature $\left({ }^{\circ} \mathrm{C}\right)$ & Pressure (MPa) & Holding Time (Min) & Matrix Behavior \\
\hline A & $\begin{array}{l}550 \\
560 \\
570 \\
580\end{array}$ & 80 & $\begin{array}{c}30 \\
\text { (Holding time at final } \\
\text { process temperature) }\end{array}$ & $\begin{array}{l}\text { Dendrite arm } \\
\text { Dendrite arm } \\
\text { Spheroidization } \\
\text { Needle shape }\end{array}$ \\
\hline B & $\begin{array}{l}550 \\
560 \\
570\end{array}$ & $\begin{array}{c}\mathrm{Pl} \text { process at } 450^{\circ} \mathrm{C} \\
(80 \mathrm{MPa} \text { to } 0 \mathrm{MPa})\end{array}$ & $\begin{array}{c}10 \\
\text { (Holding time at } 450{ }^{\circ} \mathrm{C} \text { ) }\end{array}$ & Spheroidization \\
\hline $\mathrm{C}$ & $\begin{array}{l}550 \\
560 \\
570\end{array}$ & $\begin{array}{l}\mathrm{Pl} \text { process at } 450{ }^{\circ} \mathrm{C} \\
(80 \mathrm{MPa} \text { to } 0 \mathrm{MPa})\end{array}$ & $\begin{array}{c}30 \\
\text { (Holding time at } 450{ }^{\circ} \mathrm{C} \text { ) }\end{array}$ & Spheroidization \\
\hline
\end{tabular}

The heat flow-temperature relationships were analyzed by differential scanning calorimetry (DSC; Rigaku DSC8270, Osaka, Japan). An aluminum chip sample (8 mg) was placed in an alumina pan and heated to $630^{\circ} \mathrm{C}$ at $10^{\circ} \mathrm{C} / \mathrm{min}$ in a nitrogen atmosphere to prevent oxidation, and the sample was cooled to room temperature. The relative densities of the samples prepared in groups A, B, and C were measured by Archimedes' method. The microstructures of the samples were investigated by optical microscopy (OM; Leica DM 2700M RL/TL, Wetzlar, Germany), scanning electron microscopy (SEM; S-4800 Hitachi, Tokyo, Japan), and energy-dispersive X-ray spectroscopy (EDX; Horiba EX-250 X-stream, Tokyo, Japan). The mechanical properties of the fabricated samples were evaluated by a uniaxial compression test (Shimadzu TCE-N300-CE, Kyoto, Japan). Rectangular samples of volume $5 \times 5 \times 10 \mathrm{~mm}^{3}$ were subjected to compression testing, and the mechanical properties of a single phase in the microstructure were investigated by the Vickers hardness test (Shimadzu HMV-2T, Kyoto, Japan).

\section{Results and Discussion}

Figure 1 shows the DSC heating curve of the base aluminum alloy used in this study. There are four endothermic peaks in the DSC heating curve, which are referred to as peak 1 , peak 2, peak 3, and peak 4, respectively. In peak 1 , the $\mathrm{Al}_{5} \mathrm{Cu}_{2} \mathrm{Mg}_{8} \mathrm{Si}_{6}$ phase first reacted at $476.5^{\circ} \mathrm{C}$. In peak 2 , melting of the eutectic Si phase was observed at $527.4{ }^{\circ} \mathrm{C}$. In peak 3 , the melting reaction of the $\mathrm{Mg}_{2} \mathrm{Si}$ phase occurred at $539.3{ }^{\circ} \mathrm{C}$. Finally, in peak 4 , the melting reaction of $\alpha$-aluminum occurred at $582.5^{\circ} \mathrm{C}$. According to Kim et al., this alloy is reported to have a liquid fraction of $48.6 \%$ at $539.7^{\circ} \mathrm{C}$ [19]. Based on these results, the SSP temperatures were set in the temperature range where the liquid fraction was close to $50 \%$ through the DSC experiments.

Figure 2 compares the relative densities of the samples formed at different SSP pressures and holding times. Groups B and C fabricated by Pl exhibited lower densities than group A, although the density improved by increasing the holding time (c.f. group C vs. group B). The theoretical density $D_{\text {high-strength aluminum }}$ of high-strength aluminum was calculated as follows:

$D_{\text {High-Strength Aluminum }}=\left(D_{A l} \times C_{A l}\right)+\left(D_{Z n} \times C_{Z n}\right)+\left(D_{S i} \times C_{S i}\right)+\left(D_{M g} \times C_{M g}\right)+\left(D_{C u} \times C_{C u}\right)$

where $D_{x}$ and $C_{x}$ denote the true density and volume fraction of element $x$ in the composition, respectively. The true densities of the elements are listed in Table 2. 


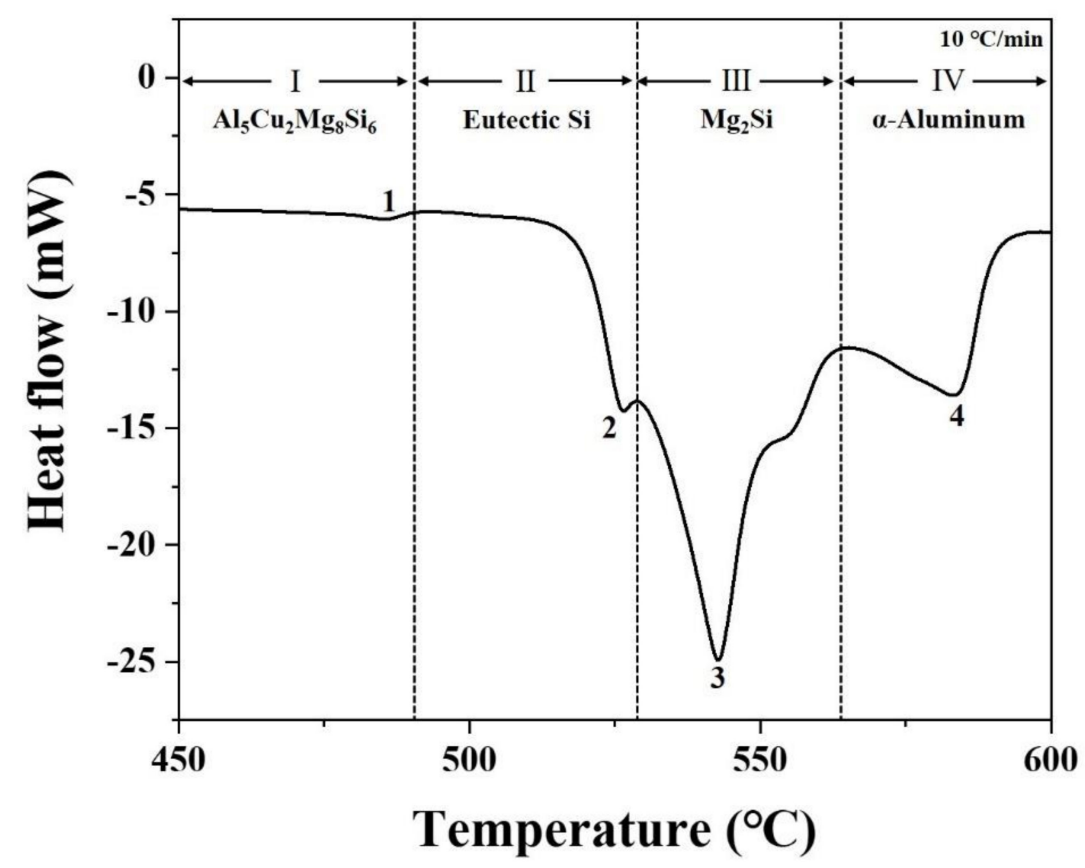

Figure 1. DSC heating curve of high-strength aluminum alloy.

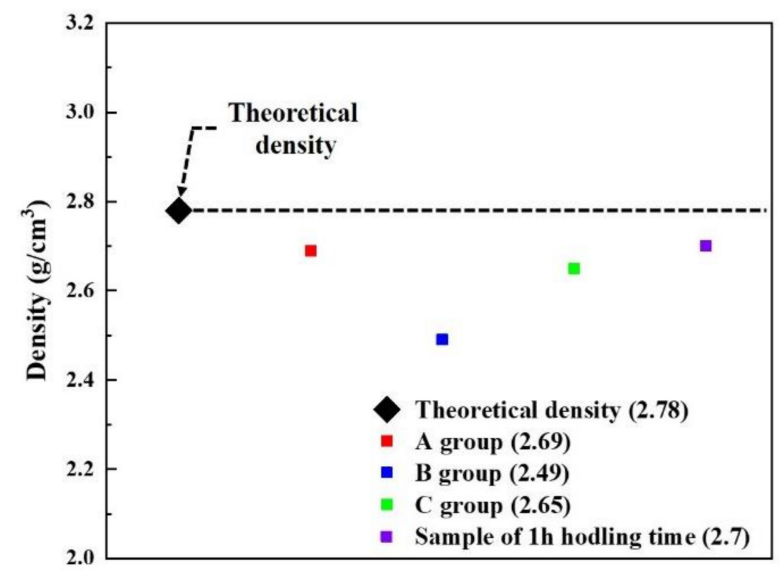

Figure 2. Relative densities of the samples prepared in groups A, B and C, with the theoretical density shown for comparison.

Table 2. Densities of the elements in the composition alloy.

\begin{tabular}{cccccc}
\hline Element Composition & Al & Zn & Si & Mg & Cu \\
\hline True density $\left(\mathrm{g} / \mathrm{cm}^{3}\right)$ & 2.7 & 7.14 & 2.33 & 1.73 & 8.96 \\
\hline
\end{tabular}

The theoretical density of high-strength aluminum calculated by Equation (1) is plotted in Figure 2 for comparison with the measured values. The relative densities of groups A, B, and C were $96.6 \%, 89.3 \%$, and $95.3 \%$ of the theoretical density of high-strength aluminum, respectively. The sharp decrease in the relative density of the group B samples can be explained by the formation of unintended micro-porosity during the Pl process of the SSP [21]. The relative density of the group C samples approached the theoretical density because the holding time was increased to $30 \mathrm{~min}$. As shown in Figure 1, the melting reaction of high-strength aluminum alloy began at $470{ }^{\circ} \mathrm{C}$. This results is likely attributable to the reduced pore volume, as the increased holding time at $450{ }^{\circ} \mathrm{C}$ enhances local liquefaction on the surface of $\mathrm{Al}$ chips [22,23]. In addition, as the holding time 
increases, the local liquefaction increases the contact area between the $\mathrm{Al}$ chips, which is expected to facilitate the heat diffusion. Therefore, it was inferred that the short holding time caused the low relative density of group B high-strength aluminum produced by the $\mathrm{Pl}$ process, whereas the longer holding time of group $\mathrm{C}$ high-strength aluminum was sufficient to achieve a near-theoretical density.

Figure 3 shows the microstructures of the samples fabricated at various process temperatures, pressures, and holding times. The optimal conditions of Al matrix spheroidization were confirmed in group A. The optimum temperature for spheroidizing the $\mathrm{Al}$ matrix was $570{ }^{\circ} \mathrm{C}$ (Figure 3c). At process temperatures of 550 and $560{ }^{\circ} \mathrm{C}$, the $\mathrm{Al}$ matrix was dendritic (Figure 3a,b, respectively). A dendritic form of the Al matrix indicates that the temperature is insufficient to form a mushy zone. In contrast, the Al matrix formed at the process temperature of $580{ }^{\circ} \mathrm{C}$ was needle-like, and dendrites and spheroids were not seen (Figure 3d). In this case, the alloy exceeded the mushy-zone temperature and the liquefaction of the $\mathrm{Al}$ matrix was complete rather than local. Under complete liquefaction and pressure effects, the sample was deformed along the stress direction. Panels e, $\mathrm{f}$, and $\mathrm{g}$ of Figure 3 are micrographs of the group B samples manufactured through the Pl process at 550,560 , and $570{ }^{\circ} \mathrm{C}$, respectively. At the optimal spheroidization temperature $\left(570{ }^{\circ} \mathrm{C}\right)$, uniformly spheroidal forms are seen in the Al matrix. Panels h, I, and j of Figure 3 are micrographs of the group $\mathrm{C}$ samples manufactured through the $\mathrm{Pl}$ process at 550,560, and $570{ }^{\circ} \mathrm{C}$, respectively. Similar to group B, the Al matrix of the sample prepared in group $\mathrm{C}$ also shows a uniform spheroidal shape, depending on the process temperature. These results can explain that the 10 and 30 min holding at $450{ }^{\circ} \mathrm{C}$ had a significant influence on the spheroidization of the group B and C samples. The cause of the microstructure difference between group $A$ and groups $B$ and $C$ is thought to be the pressure applied during the process. In the case of group A samples, $80 \mathrm{MPa}$ of pressure was applied at the final processing temperature. However, the pressure was released after holding of 10 and 30 min at $450{ }^{\circ} \mathrm{C}$ for group $\mathrm{B}$ and $\mathrm{C}$ samples. Around $450 \sim 470{ }^{\circ} \mathrm{C}$, the $\mathrm{Al}_{5} \mathrm{Cu}_{2} \mathrm{Mg}_{8} \mathrm{Si}_{6}$ phase becomes liquid and the small volume of liquid plays a critical role in spheroidization of the matrix. Under $80 \mathrm{MPa}$ pressure (group A), the small volume of liquid squeezed out through the large surface of dendrites. However, without pressure (groups B and C), the liquid formed at around $450-470^{\circ} \mathrm{C}$ remains between the dendrites and the Ostwald ripening phenomenon takes place with longer holding at temperatures below $560{ }^{\circ} \mathrm{C}$. Figure 4 schematizes the spheroidization mechanism of the Al matrix, which proceeds through rheology and Ostwald ripening during the Pl process at the mushy-zone temperature [24,25]. The microstructure of the high-strength aluminum alloy in the mushy-zone state evolves through four stages. First, the dendrite arms are deformed and broken under the applied pressure and temperature. Second, the broken dendritic arms grow into non-dendritic grains through the rheology and Ostwald ripening mechanism in the Pl process. Third, the primary $\alpha-\mathrm{Al}$ melts along the grain boundaries and grows in association with new particles. Finally, the grains become separated and spheroidization occurs in the mushyzone temperature range. Increasing the holding time to $30 \mathrm{~min}$ (group C) removed the unintended porosity found in group B, thus boosting the relative density to $95.3 \%$ of the theoretical density.

Figure 5 shows the EDX line profiles of the chemical elements of the $\mathrm{Mg}_{2} \mathrm{Si}$ phase inside the group B and C samples. No pronounced deformation appeared in the $\mathrm{Mg}_{2} \mathrm{Si}$ phase of the group B sample (Figure 5a). This result implied that deformation of the $\mathrm{Mg}_{2} \mathrm{Si}$ phase could not occur during the short holding time. In contrast, the $\mathrm{Mg}_{2} \mathrm{Si}$ phase of group $\mathrm{C}$ became coarse in size and showed some evidence of changes in its physical and mechanical properties (Figure $5 \mathrm{~b}$ ). This is interesting because the $\mathrm{Mg}_{2} \mathrm{Si}$ phase deformed in group C, although the holding time was 20 min longer in this group than in group B. In general, lengthening the holding time encourages the deformation of the reinforced phase, forming a "liquid pool" or a "liquid island" [7]. Owing to such mechanical deformation, the $\mathrm{Mg}_{2} \mathrm{Si}$ phase inside the sample of group $\mathrm{C}$ should exhibit a weaker mechanical strength than the $\mathrm{Mg}_{2} \mathrm{Si}$ phase inside the sample of group B. 

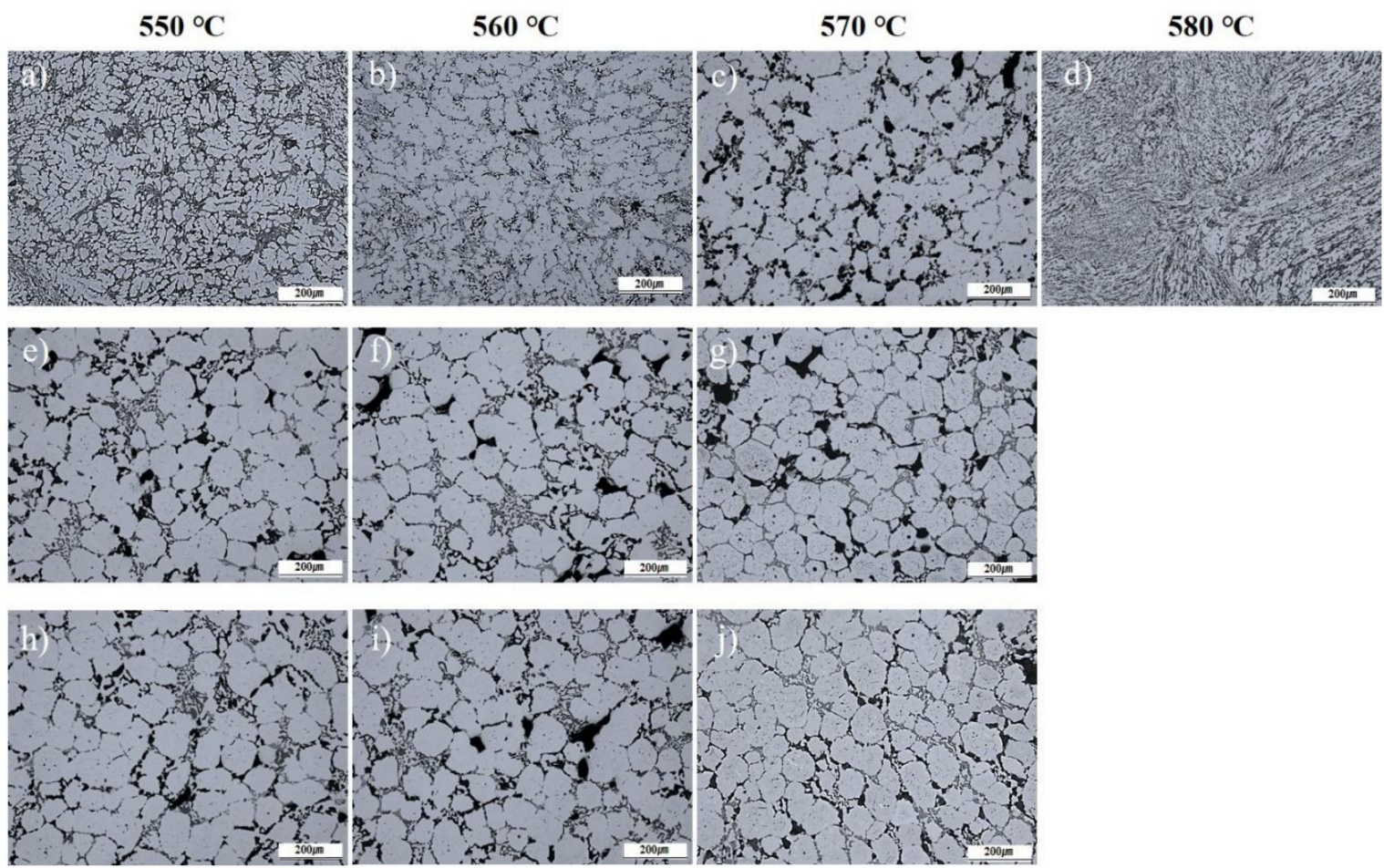

Figure 3. Optical microscopy images of the SSP-fabricated samples: (a-d) group A, (e-g) group B, and (h-j) group C.

\section{Pressure}

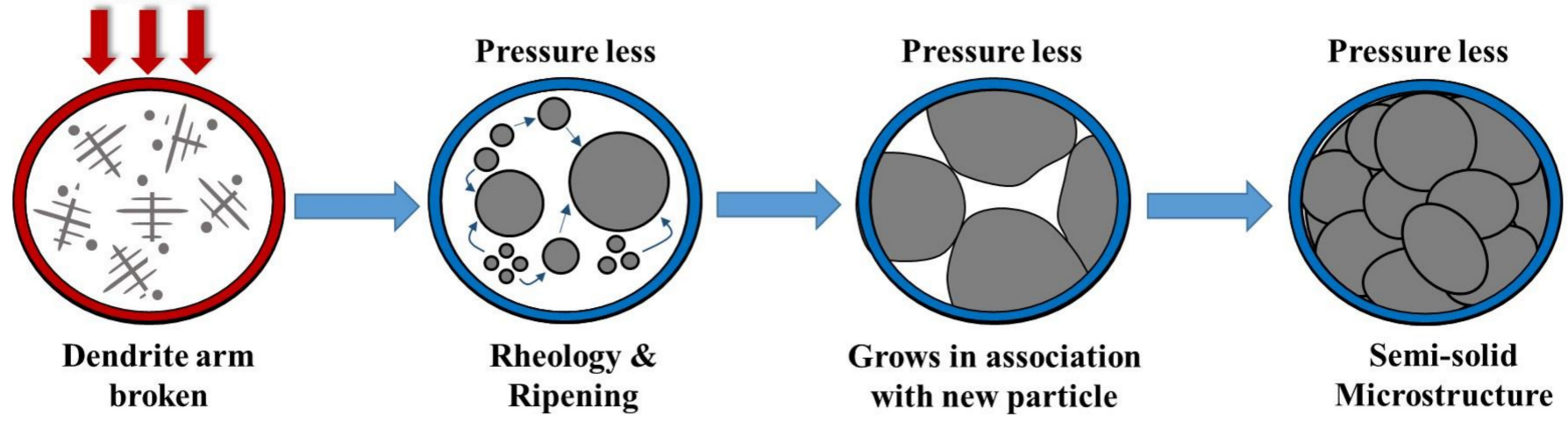

Figure 4. Schematic of SS behaviors in the Al matrix.
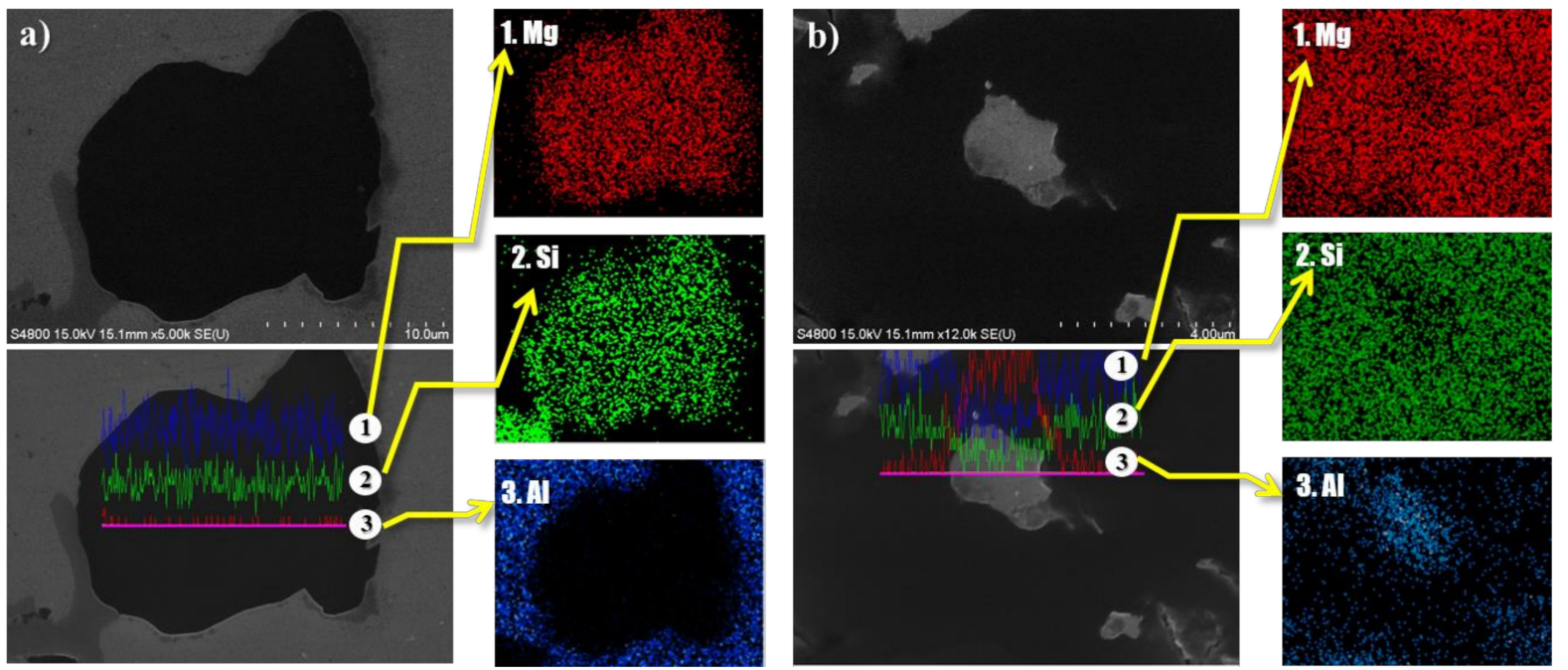

Figure 5. SEM images and EDX line profiles of the $\mathrm{Mg}_{2} \mathrm{Si}$ phase in the (a) group B and (b) C samples formed at $550{ }^{\circ} \mathrm{C}$. 
Table 3 lists the Vickers hardness values of the Al matrix, eutectic $\mathrm{Si}$, and $\mathrm{Mg}_{2} \mathrm{Si}$ phases in the sample of groups B and C. The Al matrixes and eutectic Si phases of the group B and $\mathrm{C}$ samples exhibited similar hardness values, but the hardness of the eutectic $\mathrm{Mg}_{2} \mathrm{Si}$ particle was much lower in group $\mathrm{C}$ than in group $\mathrm{B}$. The hardness of the $\mathrm{Mg}_{2} \mathrm{Si}$ phase is typically 350-750 HV [26], higher than the hardness of the $\mathrm{Mg}_{2} \mathrm{Si}$ phase inside the group C sample. The low value in the group $C$ sample was probably attributable to deformation of the $\mathrm{Mg}_{2} \mathrm{Si}$ phase during the long holding time.

Table 3. Vickers hardness in each phase of the group B and C samples.

\begin{tabular}{|c|c|c|c|c|}
\hline Sample Type & $\begin{array}{c}\text { Group B } \\
\left(550^{\circ} \mathrm{C}\right)\end{array}$ & $\begin{array}{c}\text { Group B } \\
\left(570{ }^{\circ} \mathrm{C}\right)\end{array}$ & $\begin{array}{c}\text { Group C } \\
\left(550{ }^{\circ} \mathrm{C}\right)\end{array}$ & $\begin{array}{c}\text { Group C } \\
\left(570{ }^{\circ} \mathrm{C}\right)\end{array}$ \\
\hline $\mathrm{Al}$ & 115.3 & 131.2 & 114.8 & 134.6 \\
\hline Eutectic Si & 253 & 255.6 & 253.8 & 252.3 \\
\hline $\mathrm{Mg}_{2} \mathrm{Si}$ & 378.8 & 382.5 & 262.3 & 311.2 \\
\hline
\end{tabular}

Figure 6 shows the compressive stress-strain curves of the samples in groups B and C. As shown in Figure 6, the compressive stress of the samples in both groups B and C increased with the process temperature. At $550{ }^{\circ} \mathrm{C}$, the maximum compressive strength of the sample in both groups was significantly lower than in the samples manufactured at $570{ }^{\circ} \mathrm{C}$. This result implies that increasing the process temperature reduces the pore volume inside the sample, improving the load transfer to the Al matrix and possibly homogenizing the stress distribution under compression. The maximum compressive stress was much higher in the sample of group B than in the sample of group C, probably because the strength of the $\mathrm{Mg}_{2} \mathrm{Si}$ phase was superior in group B (recall that the $\mathrm{Mg}_{2} \mathrm{Si}$ phase in the sample of group C was deformed; see Figure 5). The higher the strength of the $\mathrm{Mg}_{2} \mathrm{Si}$ phase, the higher the resistance to compressive stress when the load transfer in the $\mathrm{Al}$ matrix decreases. Additionally, in general, the compressive strength of aluminum is reported to be about 140 250 MPa [27-29]. As shown in Table 4, it was confirmed that the compressive strength of the group B and C samples prepared through the SSP improved compared to the general compressive strength of aluminum.
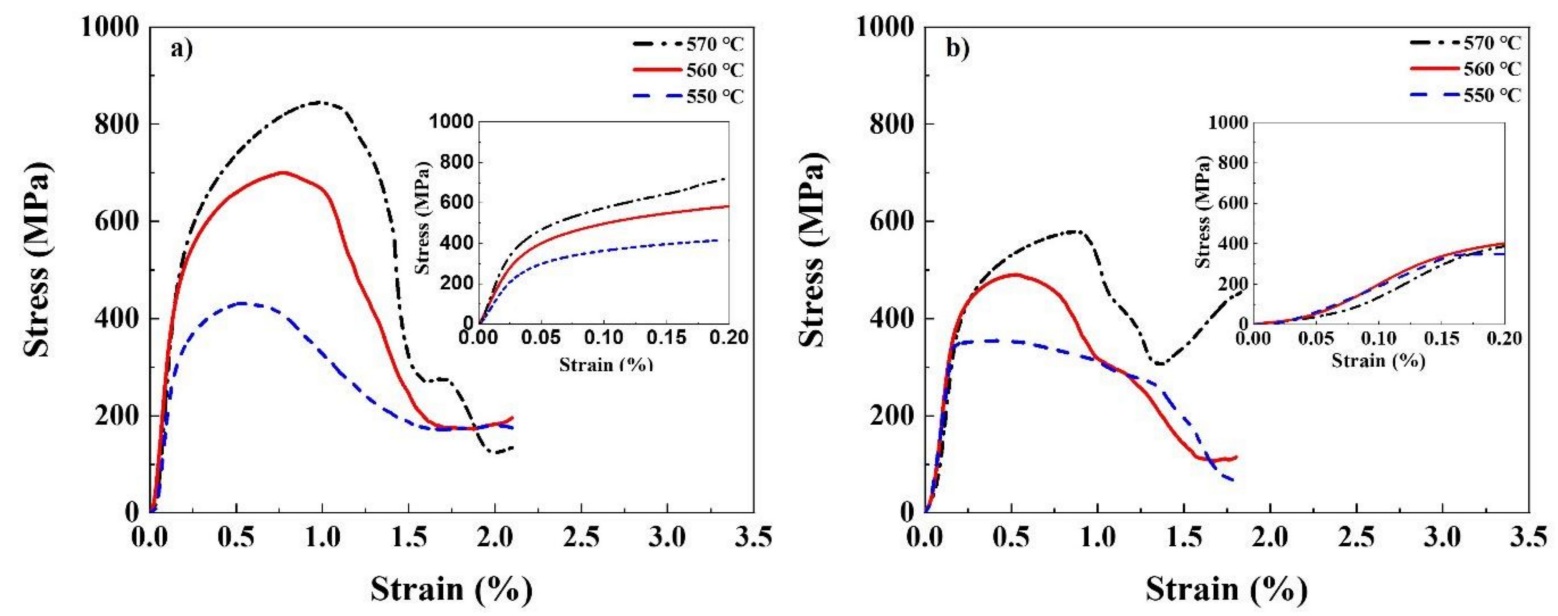

Figure 6. Compressive yield strengths of the samples formed under different processing conditions: (a) group B and (b) group C.

Table 4. Compressive yield strength of group B and C samples.

\begin{tabular}{ccccc}
\hline \multicolumn{2}{c}{ Temperature $\left({ }^{\circ} \mathbf{C}\right)$} & $\mathbf{5 5 0}$ & $\mathbf{5 6 0}$ & $\mathbf{5 7 0}$ \\
\hline Compressive & Group B & 414.9 & 582.2 & 723.7 \\
Yield strength (MPa) & Group C & 350.7 & 437.6 & 520.3 \\
\hline
\end{tabular}


Figure 7 shows the fracture behaviors of the $\mathrm{Mg}_{2} \mathrm{Si}$, eutectic $\mathrm{Si}$, and $\mathrm{Al}$ matrices in the group B and C samples under compression. Samples in both groups displayed similar fracture behaviors of each phase. The fracture mode of each phase develops in three stages, as shown in Figure 8. First, cracking begins in the elastic region as stress is concentrated in the $\mathrm{Mg}_{2} \mathrm{Si}$ phase, and micro-cracks are found only in the $\mathrm{Mg}_{2} \mathrm{Si}$ phase. Second, when the maximum compressive stress is reached, the cracks begin propagating along the $\mathrm{Mg}_{2} \mathrm{Si}$ phase (Figure $7 \mathrm{~b}, \mathrm{e}$ ). Finally, the cracks propagate along the $\mathrm{Mg}_{2} \mathrm{Si}$ phase to the eutectic $\mathrm{Si}$ and $\mathrm{Al}$ matrices (Figure $7 \mathrm{c}, \mathrm{f}$ ). The compression fracture behavior of the $\mathrm{Mg}_{2} \mathrm{Si}$ phase confirms a lower maximum compressive strength of the sample in the group $\mathrm{C}$ sample than in the group B sample. Meanwhile, panels b and c of Figure 7 confirm larger cracks in the $\mathrm{Mg}_{2} \mathrm{Si}$ phase of the group $\mathrm{C}$ sample than in the group B sample, which can be explained by the higher compressive stress of the $\mathrm{Mg}_{2} \mathrm{Si}$ phase in the group $\mathrm{C}$. The low maximum compressive stress of the sample in group $\mathrm{C}$ is probably explained by the reduced strength of the $\mathrm{Mg}_{2} \mathrm{Si}$ phase in the group $\mathrm{C}$ sample after deformation during the manufacturing process.

Elastic Region
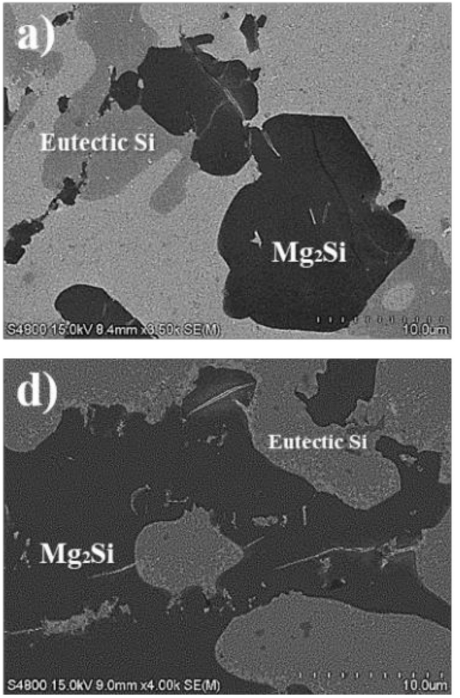

Plastic Region
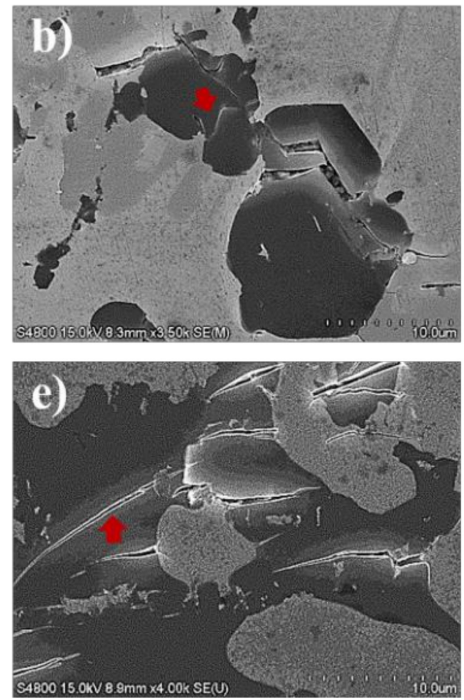

Fracture Region
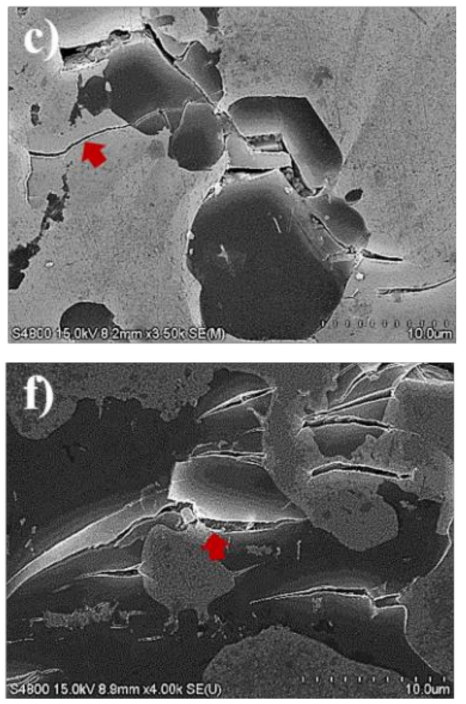

Figure 7. SEM images of the samples after compressive strength tests: (a-c) fracture behaviors of group B and (d-f) fracture behaviors of group $\mathrm{C}$ (process temperature $=570^{\circ} \mathrm{C}$ ).

\section{Compressive direction}

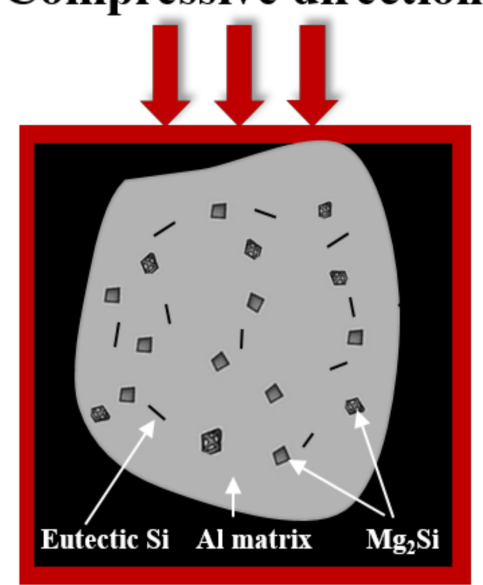

\section{Compressive direction}

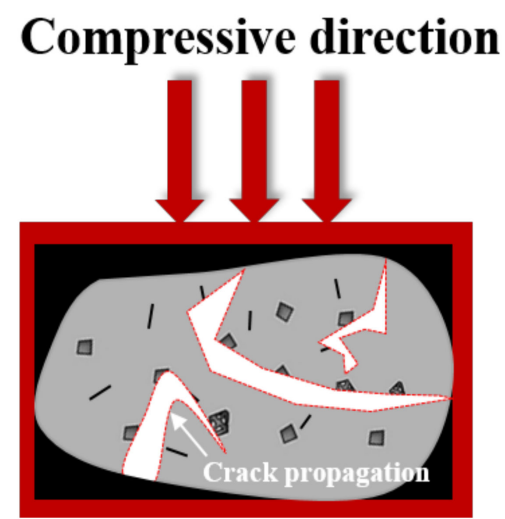

Figure 8. Schematic showing the likely fracture route of high-strength aluminum. 


\section{Conclusions}

The conclusions of this study are as follows:

1. High-strength aluminum alloy with a spheroidized aluminum matrix was successfully fabricated through a pressure-less semi-solid process at 550, 560, and $570{ }^{\circ} \mathrm{C}$. Spheroidized aluminum alloy is characterized by a higher strength than general aluminum. In the case of optimal conditions for spheroidizing the aluminum matrix, the sample could be fabricated at a temperature of $570{ }^{\circ} \mathrm{C}$ with a holding time of $30 \mathrm{~min}$ and a pressure of $80 \mathrm{MPa}$. The pressure-less process (pressure released from $80 \mathrm{MPa}$ to $0 \mathrm{MPa}$ at $450^{\circ} \mathrm{C}$ ) enabled fabricating of high-strength aluminum alloy in which the aluminum matrix was spheroidized with holding times of $10 \mathrm{~min}$ and $30 \mathrm{~min}$ at temperatures below $570{ }^{\circ} \mathrm{C}$.

2. In the microstructure, uniform spheroidization was observed in the matrix of the highstrength aluminum alloy fabricated by the pressure-less process. The spheroidization of this matrix seems to be caused by the Ostwald ripening mechanism of the dendrite arms destroyed after the pressure-less process.

3. For the high-strength aluminum alloy with a short holding time of $10 \mathrm{~min}$ in the pressure-less process, no deformation of the $\mathrm{Mg}_{2} \mathrm{Si}$ phase was observed. In contrast, a significantly deformed $\mathrm{Mg}_{2} \mathrm{Si}$ phase was observed for the high-strength aluminum alloy with a holding time of $30 \mathrm{~min}$. This result is due to changes in the mechanical properties of the $\mathrm{Mg}_{2} \mathrm{Si}$ phase with increasing holding time. In addition, it was found that the strength of the $\mathrm{Mg}_{2} \mathrm{Si}$ phase decreased as the holding time increased due to the formation of a liquid pool on the $\mathrm{Mg}_{2} \mathrm{Si}$ phase.

4. The high-strength aluminum alloy fabricated by a holding time of $30 \mathrm{~min}$ in the pressure-less process had lower compressive strength than the aluminum alloy fabricated by a holding time of $10 \mathrm{~min}$. The Vickers hardness results showed that the main reason for the low strength of the high-strength aluminum alloy is the low strength of the deformed $\mathrm{Mg}_{2} \mathrm{Si}$ due to the 30 min holding time.

Author Contributions: Planning and designing of experiments, Y.C.L.; experiments, Y.G.S. and S.S.J.; supervision, Y.C.L.; writing, Y.G.S.; review, Y.C.L.; writing-review and editing, Y.H.P. and Y.C.L. All authors have read and agreed to the published version of the manuscript.

Funding: This research was funded by the Ministry of Strategy and Finance (MSF), grant number PEO21080.

Institutional Review Board Statement: Not applicable.

Informed Consent Statement: Not applicable.

Acknowledgments: This study was conducted with the support of the Korea Institute of Industrial Technology as "Development of Root Technology for Multi-Product Flexible Production (KITECH EO-21-0008)".

Conflicts of Interest: The authors declare no conflict of interest.

\section{References}

1. Bakhtiyarov, S.; Siginer, D.A. Rheoprocessing of Semisolid Aluminum Alloys. Encycl. Alum. Its Alloy. 2019, 2, 2395-2406. [CrossRef]

2. Hassas-Irani, S.B.; Zarei-Hanzaki, A.; Bazaz, B.; Roostaei, A.A. Microstructure evolution and semi-solid deformation behavior of an A356 aluminum alloy processed by strain induced melt activated method. Mater. Des. 2013, 46, 579-587. [CrossRef]

3. Salleh, M.S.; Omar, M.Z.; Syarif, J.; Mohammed, M.N. An Overview of Semisolid Processing of Aluminium Alloys. ISRN Mater. Sci. 2013, 2013, 679820. [CrossRef]

4. Gan, Y.X.; Overfelt, R.A. Fatigue property of semisolid A357 aluminum alloy under different heat treatment conditions. J. Mater. Sci. 2006, 41, 7537-7544. [CrossRef]

5. Kang, C.G.; Choi, J.S.; Kim, K.H. Effect of strain rate on macroscopic behavior in the compression forming of semi-solid aluminum alloy. J. Mater. Process. Technol. 1999, 88, 159-168. [CrossRef]

6. Ivanchev, L.; Wilkins, D.; Govender, G.; Du Preez, W.; Bean, R. Rheo-processing of semi-solid metal alloys: A new technology for manufacturing automotive and aerospace components. S. Afr. J. Sci. 2008, 104, 257-259. 
7. Malekan, A.; Emamy, M.; Rassizadehghani, J.; Malekan, M. Effect of Isothermal Holding on Semisolid Microstructure of Al-Mg 2 Si Composites. ISRN Metall. 2012, 2012, 679820. [CrossRef]

8. Pola, A.; Tocci, M.; Kapranos, P. Microstructure and properties of semi-solid aluminum alloys: A literature review. Metals 2018, 8, 181. [CrossRef]

9. Abdelgnei, M. The effect of the rheocast process on the microstructure and mechanical properties of Al-5.7Si-2Cu-0.3Mg alloy. J. Kejuruter. 2019, 31, 317-326. [CrossRef]

10. Mohammadi, H.; Ketabchi, M. Investigation of microstructural and mechanical properties of 7075 AL alloyprepared by sima method. Iran. J. Mater. Sci. Eng. 2013, 10, 32-43.

11. Chen, Z.Z.; Mao, W.M.; Wu, Z.C. Mechanical properties and microstructures of Al alloy tensile samples produced by serpentine channel pouring rheo-diecasting process. Trans. Nonferrous Met. Soc. China 2011, 21, 1473-1479. [CrossRef]

12. Shabestari, S.G.; Parshizfard, E. Effect of semi-solid forming on the microstructure and mechanical properties of the iron containing Al-Si alloys. J. Alloys Compd. 2011, 509, 7973-7978. [CrossRef]

13. Zhao, J.W.; Wu, S. Sen Microstructure and mechanical properties of rheo-diecasted A390 alloy. Trans. Nonferrous Met. Soc. China 2010, 20, s754-s757. [CrossRef]

14. Xu, C.; Zhao, J.; Guo, A.; Li, H.; Dai, G.; Zhang, X. Effects of injection velocity on microstructure, porosity and mechanical properties of a rheo-diecast Al-Zn-Mg-Cu aluminum alloy. J. Mater. Process. Technol. 2017, 249, 167-171. [CrossRef]

15. Alipour, M.; Aghdam, B.G.; Rahnoma, H.E.; Emamy, M. Investigation of the effect of Al-5Ti-1B grain refiner on dry sliding wear behavior of an Al-Zn-Mg-Cu alloy formed by strain-induced melt activation process. Mater. Des. 2013, 46, 766-775. [CrossRef]

16. Jiang, H.; Lu, Y.; Huang, W.; Li, X.; Li, M. Microstructural evolution and mechanical properties of the semisolid Al-4Cu-Mg alloy. Mater. Charact. 2003, 51,1-10. [CrossRef]

17. Dai, W.; Wu, S.; Lü, S.; Lin, C. Effects of rheo-squeeze casting parameters on microstructure and mechanical properties of AlCuMnTi alloy. Mater. Sci. Eng. A 2012, 538, 320-326. [CrossRef]

18. Wang, F.; Zhang, W.; Xiao, W.; Yamagata, H.; Ma, C. li Microstructural evolution during reheating of A356 machining chips at semisolid state. Int. J. Miner. Metall. Mater. 2017, 24, 891-900. [CrossRef]

19. Kim, B.J.; Jung, S.S.; Hwang, J.H.; Park, Y.H.; Lee, Y.C. Effect of eutectic Mg2si phase modification on the mechanical properties of Al-8Zn-6Si-4Mg-2Cu cast alloy. Metals 2019, 9, 32. [CrossRef]

20. Kim, B.; Hwang, J.; Park, Y.; Lee, Y. Microstructural improvement of eutectic al + mg2si phases on al-zn-si-mg cast alloy with tib2 particles additions. Materials 2021, 14, 2902. [CrossRef]

21. Bonner, S.; Schaffer, G.; Yao, J.-Y. Pressure Assisted Sintering of an Aluminium Alloy. Mater. Sci. Forum 2009, 618-619, 627-630. [CrossRef]

22. Maleki, A.; Niroumand, B.; Shafyei, A. Effects of squeeze casting parameters on density, macrostructure and hardness of LM13 alloy. Mater. Sci. Eng. A 2006, 428, 135-140. [CrossRef]

23. Hashemi, H.R.; Ashoori, H.; Davami, P. Microstructure and tensile properties of squeeze cast Al-Zn-Mg-Cu alloy. Mater. Sci. Technol. 2001, 17, 639-644. [CrossRef]

24. Haghdadi, N.; Zarei-Hanzaki, A.; Heshmati-Manesh, S.; Abedi, H.R.; Hassas-Irani, S.B. The semisolid microstructural evolution of a severely deformed A356 aluminum alloy. Mater. Des. 2013, 49, 878-887. [CrossRef]

25. Nie, S.; Gao, B.; Wang, X.; Cao, Z.; Guo, E.; Wang, T. The influence of holding time on the microstructure evolution of mg-10Zn6.8Gd-4Y alloy during semi-solid isothermal heat treatment. Metals 2019, 9, 420. [CrossRef]

26. Kondoh, K.; Tsuzuki, R.; Yuasa, E. Tribological properties of magnesium matrix composite alloys dispersed with Mg2Si particles. Adv. Technol. Mater. Mater. Process. J. 2005, 7, 33-36. [CrossRef]

27. Pitchayyapillai, G.; Seenikannan, P.; Balasundar, P.; Narayanasamy, P. Effect of nano-silver on microstructure, mechanical and tribological properties of cast 6061 aluminum alloy. Trans. Nonferrous Met. Soc. China 2017, 27, 2137-2145. [CrossRef]

28. Cho, Y.H.; Kim, T.S. Estimation of ultimate strength in single shear bolted connections with aluminum alloys (6061-T6). ThinWalled Struct. 2016, 101, 43-57. [CrossRef]

29. Razak, M.I. Design and Development of Alloy Wheel. Tech. Rep. 2015, 9, 3983-3991. [CrossRef] 